British Journal of Nutrition (2020), 124, 1093-1101

doi:10.1017/S0007114520002020

(C) The Author(s), 2020. Published by Cambridge University Press. This is an Open Access article, distributed under the terms of the Creative Commons Attribution licence (http://creativecommons.org/licenses/by/4.0/), which permits unrestricted re-use, distribution, and reproduction in any medium, provided the original work is properly cited.

\title{
Street food in Eastern Europe: a perspective from an urban environment in Moldova
}

Gabriela Albuquerque $^{1}$, Marcello Gelormini ${ }^{2}$, Inês Lança de Morais $^{2}$, Sofia Sousa ${ }^{1,3}$, Susana Casal ${ }^{1,4}$, Olívia Pinho ${ }^{3,4}$, Pedro Moreira ${ }^{1,3,5}$, João Breda ${ }^{6}$, Nuno Lunet ${ }^{1,7}$ and Patrícia Padrão ${ }^{1,3 *}$

${ }^{1}$ EPIUnit - Instituto de Saúde Pública, Universidade do Porto, Rua das Taipas 135, 4050-600 Porto, Portugal

${ }^{2}$ Nutrition, Physical Activity and Obesity Programme, Division of Noncommunicable Diseases and Life-Course, WHO Regional Office for Europe, UN City, Marmorvej 51, 2100 Copenhagen, Denmark

${ }^{3}$ Faculdade de Ciências da Nutrição e Alimentação da Universidade do Porto, Rua Dr. Roberto Frias, 4200-465 Porto, Portugal

${ }^{4}$ Laboratório Associado para a Química Verde (LAQV/REQUIMTE), Laboratório de Bromatologia e Hidrologia, Faculdade de Farmácia, Universidade do Porto, Rua D. Manuel II, Apartado 55142, Porto, Portugal

${ }^{5}$ Centro de Investigação em Atividade Física, Saúde e Lazer, Universidade do Porto, Rua Dr. Plácido Costa, $4200-450$ Porto, Portugal

${ }^{6}$ WHO European Office for the Prevention and Control of Noncommunicable Diseases, WHO Regional Office for Europe, Leontyevsky Pereulok, 125009 Moscow, Russian Federation

${ }^{7}$ Departamento de Ciências da Saúde Pública e Forenses e Educação Médica, Faculdade de Medicina da Universidade do Porto, Alameda Prof. Hernâni Monteiro, 4200-319 Porto, Portugal

(Submitted 7 February 2020 - Final revision received 13 May 2020 - Accepted 3 June 2020 - First published online 9 June 2020)

\section{Abstract}

Street food is popular in Eastern Europe, but its diversity and nutritional value are unknown. This study aimed to characterise the street food environment in Chişinău, Moldova, including the vending sites and vendors, food availability and nutritional composition of foods and beverages. All street food vending sites (single point of sale) located in a 1-km buffer centred on the main public market were systematically selected ( $n$ 439; $n 328$ participants). Data on vending sites' characteristics (mobility, type of physical set-up and access to electricity), operating periods and food availability were collected. Samples of the most commonly available foods of unknown composition were collected (twentyeight home-made and twenty-four industrial). Macronutrients, Na and $\mathrm{K}$ were quantified through chemical analysis. Fruits, beverages and food other than fruits were available in $2 \cdot 5,74.3$ and $80.8 \%$ of the vending sites, respectively. Among the latter, $66 \cdot 4 \%$ sold only industrial foods (e.g. pretzels, biscuits, wafers, chocolate and ice cream), $21.5 \%$ only home-made (e.g. savoury and sweet pastries) and $12.1 \%$ both. Home-made foods presented larger serving sizes and energy/serving (median $\mathrm{kJ} /$ serving: $1312.5 \mathrm{v} .670 \cdot 3, P=0.022$ ); industrial foods were more energydense (median kJ/100 g: 1797.0 v. 1269.8, $P=0.002$ ). High SFA, trans-fat and Na contents were found, reaching $10 \cdot 9 \mathrm{~g} / \mathrm{serving}, 1.4 \mathrm{~g} / \mathrm{serving}$ and $773.7 \mathrm{mg} /$ serving, respectively. Soft drinks and alcoholic beverages were available in 80.7 and $42.0 \%$ of the vending sites selling beverages, respectively. Concluding, industrial snacks and home-made pastries high in Na and unhealthy fat were frequent in Chişinău. Prevention of dietrelated diseases in Moldova may benefit from the improvement of the nutritional profile of street food.

Key words: Eastern Europe: Food processing: Nutritional value: Ready-prepared foods: Street food

Eastern Europe is currently facing nutrition transition. Over the last three decades, there has been an increase in energy availability, mostly due to increased availability of animal, fat, sugar and high-protein foods ${ }^{(1,2)}$. High consumption of red and processed meat, contrasting with low consumption of fruits, vegetables, legumes, whole grains, nuts and seeds, has also been described ${ }^{(3)}$. A concurrent increase in the burden of non-communicable diseases (NCD) has been reported ${ }^{(2,3)}$, which is a well-described epidemiological characteristic of nutrition transition $^{(4)}$. In Moldova, overweight and obesity show an increasing trend; the most recent estimates indicate a prevalence of approximately $20.0 \%$ of obesity among adults. CVD, cancer and other NCD are the leading causes of death (59.0, $15 \cdot 0$ and $16 \cdot 0 \%$, respectively) $)^{(5)}$.

Typical socio-economic changes in transitional societies include an increase in the urban working force, particularly

Abbreviations: NCD, non-communicable disease; TFA, trans-fatty acid

* Corresponding author: Patrícia Padrão, email patriciapadrao@fcna.up.pt 
among women, which is in turn associated with increased consumption of food away from home ${ }^{(6)}$, such as street food. The definition of street food was proposed by the FAO and the WHO, as 'ready-to-eat foods and beverages prepared and/or sold by vendors or hawkers especially in the streets and other similar places ${ }^{,(7,8)}$. The convenience and affordability ${ }^{(9,10)}$ make street food accessible, frequently replacing home meals ${ }^{(10,11)}$. In Eastern European countries, it is part of the cultural heritage and gastronomy, reflecting the availability of local food products, culinary practices, lifestyles and consumer preferences ${ }^{(12,13)}$.

Current literature on street food is mainly focused on food safety, disregarding topics such as the types of foods available and their nutritional composition ${ }^{(10,14,15)}$. Although a few studies have estimated that street food largely contributes to the total intake of fat, trans-fatty acids (TFA), salt and sugar ${ }^{(10)}$, to our knowledge, no research on street food has been conducted in this world region. Furthermore, Moldova is one of the Eastern European countries where nationally representative data on food availability and dietary habits are scarce ${ }^{(16)}$. The aim of this study was to characterise the street food environment in Chişinău, the capital city of Moldova, including the vending places and food availability, as well as the nutritional composition of the most commonly available foods and beverages.

\section{Methods}

This study was implemented within the scope of the FEEDcities project, supported by the WHO - Europe, which used a stepwise standardised methodology to characterise the street food environment in countries in Central Asia and Eastern Europe ${ }^{(17)}$. In this study, specifically, step 1 comprised identification of street food vending sites and characterisation of vending sites, vendors and products available, by direct observation and by invitation of street food vendors to answer additional questions. Step 2 comprised collection of samples of the most frequently available foods for chemical analysis.

\section{Setting and study design}

This cross-sectional evaluation was conducted between June and August 2016 in Chişinău, the capital city of Moldova. Moldova is a lower-middle-income country, with an estimated urbanisation rate of $42.5 \%$ in $2016^{(18)}$. Approximately 690000 individuals were living in Chişinău, corresponding to $20 \%$ of the whole country population $\left(2 \cdot 8\right.$ million in 2016) ${ }^{(19)}$.

In a site visit conducted for preparing fieldwork, previous to data collection, members of the research team observed that in this city, most street food vendors were concentrated in the central market and its surroundings, in the Centru sector, the central business district. To define the study area, a 1-km diameter buffer was built around the central market (with the centroid in its geographic midpoint), covering it and its surroundings. To define the sample size, it was assumed, for a design effect up to $1 \cdot 5$, that a sample size of approximately 300 vending places would yield $95 \%$ CI up to $15 \%$ wide for observed proportions ranging between approximately 30 and $70 \%$, and $95 \%$ CI for means with a width of approximately $30 \%$ of the observed standard deviation.

Eligible vending sites (single point of sale regardless of whether one or more vendors were operating) were defined as the business establishments selling ready-to-eat food, including beverages and/or snacks. This included mobile vendors, as well as sellers with semi-static or stationary vending units. The exclusion criteria were the following: (1) food establishments with four permanent walls; (2) permanent storefront businesses; (3) street vendors selling exclusively non-food products or raw foods not ready-to-eat and (4) food stalls and carts which were part of permanent stores or licensed establishments.

\section{Data collection: vending sites, vendors and food availability}

The study area was systematically assessed in nine consecutive working days, between 27 June and 6 July. After registering the global positioning system (GPS) coordinates of each vending site, ten interviewers collected the following information, through direct observation: sex of the vendor, mobility of the vending site and type of physical set-up. Stationary vending sites were further classified into formal (stand (an upright structure where street food is prepared and/or displayed), dukoni (restaurant serving traditional fast food selling directly on the street through an open window), kiosk (small open-fronted hut or cubicle where typically newspapers are sold, as well as a sort of foods and beverages), kvass barrel (vending site consisting of a portable metal barrel containing kvass, a traditional fermented beverage made from rye bread, supported by an upright structure), table with chairs for customers (displayed in the public street and not being part of a permanent storefront business) or truck (large motorised vehicle, such as a van or trailer, equipped to cook, prepare, serve and/or sell food)) or informal (bench with table, pushcart and other improvised sites as freezers, refrigerators or coolers) (online Supplementary Table S3).

Afterwards, interviewers approached the vendor to explain the study objectives and procedures and to ask for express consent to participate in the study. When the vendor agreed, the interviewers carried out computer-assisted personal interviews, enquiring about vending site ownership and food availability, including products sold and serving sizes. Given the limited time of food vendors operating mobile vending sites to answer the questionnaire, additional questions regarding vending sites' characteristics (access to electricity) and food vending activity (operating periods - during the week; during the year and under which weather conditions) were asked only to vendors operating on stationary vending sites. Additional information is available on the protocol of this study, including the structure of the questionnaire ${ }^{(17)}$

A total of 439 eligible vending sites were identified in the study area, and all vendors were invited to participate; 328 (74.7\%) vendors accepted. No statistically significant differences were found between participant and non-participant vendors regarding the type of vending site they were operating (online Supplementary Table S1).

Foods available were grouped according to their nature, into fruit (product in natura, either fresh or dry), beverages (any alcoholic and non-alcoholic drink) or food other than fruit. According to FAO standards ${ }^{(11)}$, food other than fruit was further classified as home-made (self-prepared food products, at home or on the street, even if using industrial ingredients) or industrial 
(commercially prepared food products sold by street vendors without further preparation and/or cooking, encompassing both processed and unprocessed foods $\left.{ }^{(20)}\right)$. Home-made food was also grouped in 'cooked', 'prepared but uncooked' and 'uncooked and unprepared'. Beverages were further classified into soft drinks, water, fruit juice-based drinks, fresh fruit juice-based drinks, milk, milk-based drinks, alcoholic beverages, energy drinks, coffee, tea or traditional beverages.

\section{Food sample collection}

Following the computation of the frequency of each of the identified foods and beverages across all the vending sites included in the study ( $n$ 328), samples of the most commonly available foods and beverages of unknown composition, that is, for which there was an absence of standardised information on nutritional composition, including nutrition labels or food composition tables, were collected for nutritional composition assessment. The most frequent home-made foods $(n 7)$ were savoury placintă (placintă: fried pastry, usually made from dough made of flour, water and sunflower oil, filled with cheese, vegetables, meat or potatoes or sweet fillings, usually served in a pie shape, but may have various shapes), sausage roll, pateuri (traditional fried pastry made from leavened dough filled with cheese, vegetables or meat, usually an oval shape and served in individual portions), sweet roll/chifla (sweet bun made of leavened dough, either flaky or brioche type, usually filled with a chocolate, vanilla or cherry cream), cheburec (traditional fried savoury pastry generally filled with meat such as chicken or beef), sweet placintă and sweet doughnut. The most frequent industrial foods ( $n$ 6) were biscuits, chocolates, candies, chewing gums, croutons and sunflower seeds in natura, but, given that the expected nutritional composition of candies, chewing gums and sunflower seeds in natura does not vary widely, the following most available industrial foods were selected: wafers, ice cream and pretzels. A local industrial beverage, kvass, was additionally selected for collection, given its full availability in this setting and unknown composition. Four samples of each of these items (hereafter referred to as 'food', although this beverage was included) were collected from different vending sites. For one food (cheburec), it was only possible to collect two samples, and for two other foods (plăcintă and pateuri), five samples were purchased. A total of fifty-two samples (twenty-eight home-made and twenty-four industrial) were collected. Online Supplementary Table S4 displays one example of each of the street foods collected, along with a brief description for the 'local foods'.

The definition of the vending sites where the food samples were collected was carried out according to a standardised procedure: in each day, ten coordinates were randomly selected from the list of the GPS coordinates of the eligible vending sites previously assessed. A sample of each food product, corresponding to one serving, was bought whenever possible at these vending sites. If not possible, a systematic selection procedure was followed, in which field researchers start moving north from that point and change direction clockwise (first east, then south, then west, then north again) whenever the limits of the study area or a physical barrier (such as a wall or a canal) are met, until reaching vending sites where these foods were available. In each vending site, only one sample of home-made or industrial food was obtained. The fifty-two food samples were collected in seven consecutive days.

\section{Nutritional composition assessment}

After collection, samples were homogenised, weighed and stored in a freezer $\left(-18^{\circ} \mathrm{C}\right)$ until the nutritional composition assessment, which included the analysis of (a) moisture, by oven drying at $103^{\circ} \mathrm{C}$ until constant weight; (b) protein, by the Kjedahl method with a conversion factor of $6 \cdot 25$; (c) fat, by the Soxhlet method, (d) total minerals by dry ashing at $500^{\circ} \mathrm{C}$, (e) total carbohydrates plus fibre by difference and (f) energy value by the Atwater general factors, all following the standard Association of Analytical Communities ${ }^{(21)}$ routine analysis in the Laboratory of Bromatology of the University of Porto (LAQV/ REQUIMTE), a partner in the FEEDcities project ${ }^{(17)}$. For the analysis of the fatty acid composition, fat was extracted separately with organic solvents followed by cold transesterification $^{(22)}$. Separation of the methyl esters was achieved by GC with flame ionisation detection, using a column specific for cis/trans separation (Agilent J\&W Select FAME, $50 \mathrm{~m}$ ) and reference standards for calibration (Supelco). The results are expressed on a relative fatty acids basis and grouped as SFA, MUFA, PUFA, $n-3$ and $n-6$ fatty acids (TFA). Na and $\mathrm{K}$ were analysed following a validated flame photometric $\operatorname{method}^{(23)}$. The analytical results were the average of two determinations per food sample. A third determination was conducted only when the first two were not in agreement; in this case, the average of the two concordant results was calculated. All the analytical results were expressed by serving size, in $g$.

\section{Statistical analysis}

The vending sites and their food availability were characterised through absolute and relative frequencies (categorical variables). Pearson's $\chi^{2}$ and Fisher's exact tests were used to identify statistically significant differences between stationary and mobile vending sites and between formal and informal stationary vending sites.

Regarding the nutritional composition assessment, mean serving sizes per food, in g, were calculated as the mean weight of the four individual samples collected for each of the foods. Likewise, per-serving levels of each nutrient were calculated as the mean content of the four individual samples and expressed in $\mathrm{g} / \mathrm{serving}$ (macronutrients) or $\mathrm{mg} /$ serving (micronutrients). Results were presented for each food, as the mean and range of energy $(\mathrm{kJ})$, carbohydrates, protein, water, total fat, including SFA, MUFA, PUFA, $n-3$ fatty acids, $n$ - 6 fatty acids, TFA, $\mathrm{Na}$ and $\mathrm{K}$ per serving and molar Na:K ratios. To convert energy in $\mathrm{kJ}$ to $\mathrm{kcal}$, the values should be divided by $4 \cdot 184$. To calculate individual molar $\mathrm{Na}: \mathrm{K}$ ratios, contents of $\mathrm{Na}$ and $\mathrm{K}$ of each sample were converted into mmol based on their molar weights, $23.0 \mathrm{~g} / \mathrm{mol}$ and $39.1 \mathrm{~g} / \mathrm{mol}$, respectively ${ }^{(24)}$. The energy content of home-made and industrial foods was compared using the non-parametric Mann-Whitney $U$ test. A critical 
Table 1. Characteristics of street food vending sites and street food availability, by type of vending site in Chişinău, Moldova $(n 328)$ (Numbers and percentages)

\begin{tabular}{|c|c|c|c|c|c|c|c|}
\hline & & & \multicolumn{4}{|c|}{ Type of vending site } & \multirow[b]{3}{*}{$P$} \\
\hline & \multicolumn{2}{|c|}{ Total ( $n$ 328) } & \multicolumn{2}{|c|}{$\begin{array}{c}\text { Stationary } \\
(\text { (n 314) }\end{array}$} & \multicolumn{2}{|c|}{ Mobile ( $n$ 14) } & \\
\hline & $n$ & $\%$ & $n$ & $\%$ & $n$ & $\%$ & \\
\hline \multicolumn{8}{|l|}{ Vending sites characteristics } \\
\hline Food vendor sex (women) & 289 & $88 \cdot 1$ & 280 & $89 \cdot 2$ & 9 & $64 \cdot 3$ & $0.005^{\star}$ \\
\hline Food vendor ownership & 34 & $10 \cdot 4$ & 24 & $7 \cdot 6$ & 10 & 71.4 & $<0.001^{*}$ \\
\hline Access to drinking water & 317 & $96 \cdot 7$ & 303 & 96.5 & 14 & $100 \cdot 0$ & 0.476 \\
\hline Access to toilet facility & 318 & $97 \cdot 0$ & 306 & 97.5 & 12 & $85 \cdot 7$ & $0.012^{*}$ \\
\hline \multicolumn{8}{|l|}{ Food availability } \\
\hline Fruit & 8 & 2.5 & 8 & 2.6 & 0 & 0.0 & 1.000 \\
\hline Food other than fruit & 265 & $80 \cdot 8$ & 252 & $80 \cdot 3$ & 13 & $92 \cdot 9$ & 0.242 \\
\hline Industrial & 176 & $66 \cdot 4$ & 173 & 68.7 & 3 & $23 \cdot 1$ & $<0.001 \dagger$ \\
\hline Home-made and industrial & 32 & $12 \cdot 1$ & 31 & $12 \cdot 3$ & 1 & $7 \cdot 7$ & \\
\hline Home-made & 57 & $21 \cdot 5$ & 48 & $19 \cdot 1$ & 9 & $69 \cdot 2$ & \\
\hline Home-made cooked $\ddagger$ & 87 & 97.8 & 77 & 97.5 & 10 & $100 \cdot 0$ & 1.000 \\
\hline Home-made prepared but not-cooked $\ddagger$ & 21 & 23.6 & 21 & $26 \cdot 6$ & 0 & 0.0 & 0.109 \\
\hline Home-made non-prepared and non-cooked $\ddagger$ & 1 & $1 \cdot 1$ & 1 & $1 \cdot 3$ & 0 & 0.0 & 1.000 \\
\hline Beverages $\S$ & 243 & $74 \cdot 3$ & 240 & $76 \cdot 7$ & 3 & 21.4 & $<0.001 \dagger$ \\
\hline Soft drinks & 196 & $80 \cdot 7$ & 194 & $80 \cdot 8$ & 2 & $66 \cdot 7$ & 0.477 \\
\hline Water & 187 & $77 \cdot 0$ & 186 & 77.5 & 1 & 33.3 & 0.134 \\
\hline Fruit juice-based drinks & 140 & 57.6 & 139 & $57 \cdot 9$ & 1 & 33.3 & 0.576 \\
\hline Alcoholic beverages\| & 102 & $42 \cdot 0$ & 102 & 42.5 & 0 & 0.0 & 0.266 \\
\hline Coffee & 79 & 32.5 & 76 & 31.7 & 3 & $100 \cdot 0$ & $0.033 \dagger$ \\
\hline Energy drinks & 76 & $31 \cdot 3$ & 76 & $31 \cdot 7$ & 0 & 0.0 & 0.554 \\
\hline Tea & 69 & 28.4 & 66 & 27.5 & 3 & $100 \cdot 0$ & $0.022 \dagger$ \\
\hline Fresh fruit juice-based drinks & 17 & 7.0 & 17 & $7 \cdot 1$ & 0 & 0.0 & 1.000 \\
\hline Milk & 6 & 2.5 & 6 & 2.5 & 0 & 0.0 & 1.000 \\
\hline Milk-based drinks & 3 & $1 \cdot 2$ & 3 & 1.3 & 0 & 0.0 & 1.000 \\
\hline Traditional dairy beverages ${ }^{\star \star}$ & 2 & 0.8 & 2 & 0.8 & 0 & 0.0 & 1.000 \\
\hline
\end{tabular}

* Statistically significant differences according to Pearson's $\chi^{2}$ test, for a confidence level of $95 \%(P<0.05)$.

† Statistically significant differences according to Fisher's exact test, for a confidence level of $95 \%(P<0.05)$.

$\ddagger$ Sum of the values for this variable is higher than the total number of home-made foods, as each vendor could have available foods prepared in different ways.

$\S$ Sample size for these variables is smaller, due to missing data $(n 313)$.

\| Alcoholic beverages: beer ( $n$ 60), kvass ( $n$ 45), alcopop ( $n$ 7), distilled beverages $(n 3)$ and wine $(n 2)$.

I Milk-based drinks: milk drinks and cocktails $(n 1)$ and hot chocolate $(n 2)$.

${ }^{\star *}$ Traditional dairy beverages: kephyr $(n 1)$ and yogurt $(n 1)$.

level of significance $(P)<0.05$ was considered statistically significant.

Statistical analysis was performed using the software STATA $®$ version 11.0 for Windows®.

\section{Ethical considerations}

This study was conducted according to the Declaration of Helsinki, and all procedures involving human subjects were approved by the Ethics Committee of the Institute of Public Health of the University of Porto (CE16058). Verbal informed consent was obtained from all vendors.

\section{Results}

\section{Food vendors and vending sites}

Over four in every five street vendors were women ( $88.1 \%$ ), and a small proportion were owners (10.4\%), except in mobile vending sites, where most vendors $(71.4 \%)$ were owners of the business (Table 1).

Most vending sites were located inside the market (online Supplementary Fig. 1) and were stationary (95.7\%), of which the most frequent physical set-ups were stands $(35.4 \%)$ or kiosks (29.6\%) (online Supplementary Table S1). Most stationary vending sites had access to electricity (88.9\%), drinking water (96.5\%) and toilet facilities (97.5\%) and were operating $7 \mathrm{~d}$ /week ( $87.3 \%$ ), all year long ( $79.9 \%)$ and under every type of weather $(81.2 \%)$. The informal vending sites were less likely to be operating the whole year ( $43.1 v .87 \cdot 1 \%$, $P<0.001)$ and under every type of weather (56.9 v. $85.9 \%$, $P<0.001$ ) (online Supplementary Table S2).

\section{Food availability}

Fruit and beverages were sold, respectively, in 2.5 and $74.3 \%$ of the vending sites. Food other than fruit was sold in $80.8 \%$ of the vending sites, of which $66.4 \%$ sold only industrial foods (e.g. pretzels, biscuits, wafers, chocolate and ice cream), $21.5 \%$ only home-made (e.g. savoury - cheburec, pateuri, plăcintă, sausage roll - and sweet pastries - plăcintă, chiflă and doughnut) and $12.1 \%$ both home-made and industrial foods. The mobile vending sites were more likely to sell only home-made foods $(69 \cdot 2 v \cdot 19 \cdot 1 \%, P<0 \cdot 001)$ and less likely to sell only industrial foods (23.1 v. 68.7\%, $P<0.001)$. Most home-made foods were cooked $(97 \cdot 8 \%)$. Stationary vending sites were the only ones selling fruit, and where beverages were more frequently $(76.7$ 
Table 2. Nutritional composition (energy and macronutrients) of the street food samples evaluated by laboratorial analysis, per serving (Mean values and ranges)

\begin{tabular}{|c|c|c|c|c|c|c|c|c|c|c|c|c|c|}
\hline & \multirow[b]{2}{*}{$n$} & \multicolumn{2}{|c|}{$\begin{array}{l}\text { Serving size } \\
\text { (g/serving) }\end{array}$} & \multicolumn{2}{|c|}{$\begin{array}{c}\text { Energy } \\
(\mathrm{kJ} / \text { serving) }\end{array}$} & \multicolumn{2}{|c|}{$\begin{array}{c}\text { Protein } \\
\text { (g/serving) }\end{array}$} & \multicolumn{2}{|c|}{$\begin{array}{l}\text { Carbohydrates } \\
\text { (g/serving) }\end{array}$} & \multicolumn{2}{|c|}{$\begin{array}{c}\text { Total fat } \\
\text { (g/serving) }\end{array}$} & \multicolumn{2}{|c|}{ Water (g/serving) } \\
\hline & & Mean & Min-max & Mean & Min-max & Mean & Min-max & Mean & Min-max & Mean & Min-max & Mean & Min-max \\
\hline \multicolumn{14}{|l|}{ Industrial food } \\
\hline Biscuits & 4 & 33 & $33-33$ & 696.4 & $663 \cdot 0-725 \cdot 5$ & $2 \cdot 0$ & $1 \cdot 4-2 \cdot 8$ & 21.9 & $21 \cdot 3-22 \cdot 5$ & 7.9 & $6 \cdot 7-8 \cdot 8$ & $1 \cdot 2$ & $0.6-1.8$ \\
\hline Chocolate & 4 & 88 & $82-98$ & $1787 \cdot 6$ & $1683 \cdot 9-1990 \cdot 8$ & $5 \cdot 0$ & $1 \cdot 0-9.8$ & $63 \cdot 2$ & $44 \cdot 1-83 \cdot 3$ & $17 \cdot 1$ & $9 \cdot 2-30 \cdot 6$ & 1.9 & $0.6-3.7$ \\
\hline Ice cream & 4 & 56 & $33-71$ & $624 \cdot 7$ & $424.0-886.8$ & $2 \cdot 1$ & $1 \cdot 2-2 \cdot 9$ & $18 \cdot 3$ & $7 \cdot 4-26.5$ & $7 \cdot 5$ & $3.7-10.5$ & $27 \cdot 3$ & $16 \cdot 2-31 \cdot 9$ \\
\hline Pretzels & 4 & 35 & 35-35 & $601 \cdot 6$ & $574 \cdot 3-627 \cdot 7$ & 3.4 & $3 \cdot 2-3 \cdot 7$ & $25 \cdot 3$ & $24 \cdot 4-27 \cdot 3$ & $3 \cdot 2$ & $1 \cdot 6-4 \cdot 3$ & $2 \cdot 0$ & $1.9-2.2$ \\
\hline Wafers & 4 & 89 & $81-94$ & $1909 \cdot 5$ & $1788 \cdot 7-2120 \cdot 7$ & 4.5 & $3 \cdot 5-5 \cdot 2$ & $59 \cdot 0$ & $52.5-68.0$ & 22.4 & $17 \cdot 6-30 \cdot 6$ & 1.9 & $0.9-2.8$ \\
\hline \multicolumn{14}{|l|}{ Home-made food } \\
\hline Cheburec & 2 & 117 & $98-137$ & 1503.9 & $1175 \cdot 3-1832 \cdot 5$ & 9.9 & $8.3-11.4$ & $47 \cdot 8$ & $39 \cdot 9-55 \cdot 8$ & $14 \cdot 3$ & $9 \cdot 8-18 \cdot 8$ & 43.5 & $38 \cdot 7-48 \cdot 3$ \\
\hline Pateuri & 5 & 129 & 58-293 & 1588.5 & $714 \cdot 7-3591 \cdot 3$ & $9 \cdot 6$ & $4 \cdot 2-14 \cdot 2$ & $44 \cdot 0$ & $26 \cdot 5-90 \cdot 6$ & $18 \cdot 3$ & $3 \cdot 6-48 \cdot 8$ & $54 \cdot 7$ & $19 \cdot 4-134 \cdot 7$ \\
\hline Sausage roll & 4 & 125 & $100-149$ & $1322 \cdot 8$ & $1130 \cdot 3-1686 \cdot 9$ & 11.9 & $9.9-13.5$ & $40 \cdot 9$ & $29 \cdot 9-59 \cdot 7$ & $11 \cdot 7$ & $10 \cdot 8-12 \cdot 7$ & $57 \cdot 5$ & $42 \cdot 5-76 \cdot 7$ \\
\hline Savoury plăcintă & 5 & 118 & $90-157$ & $1587 \cdot 4$ & $1174 \cdot 7-2450 \cdot 0$ & $10 \cdot 1$ & $6 \cdot 6-12 \cdot 1$ & 44.5 & $31 \cdot 2-57 \cdot 0$ & $17 \cdot 9$ & $8 \cdot 3-34 \cdot 6$ & 43.6 & $32 \cdot 9-52 \cdot 6$ \\
\hline Sweet doughnut & 4 & 49 & $34-61$ & $760 \cdot 9$ & $533 \cdot 8-967 \cdot 6$ & $2 \cdot 7$ & $1.8-3.9$ & $21 \cdot 2$ & $14 \cdot 7-29 \cdot 9$ & $9 \cdot 6$ & $6 \cdot 9-14.0$ & $14 \cdot 8$ & $10 \cdot 9-18 \cdot 2$ \\
\hline Sweet plăcintă & 4 & 101 & $82-143$ & $1359 \cdot 0$ & $937 \cdot 1-1661 \cdot 7$ & 4.9 & $3 \cdot 1-5 \cdot 8$ & $52 \cdot 9$ & $40 \cdot 6-68.7$ & $10 \cdot 4$ & $5 \cdot 5-13 \cdot 2$ & 31.9 & $18 \cdot 5-56 \cdot 6$ \\
\hline
\end{tabular}

Min, minimum; Max, maximum.

* To convert energy in $\mathrm{kJ}$ to $\mathrm{kcal}$, the values should be divided by 4.184

Table 3. Nutritional composition (fatty acid profile) of the street food samples evaluated by laboratorial analysis, per serving (Mean values and ranges)

\begin{tabular}{|c|c|c|c|c|c|c|c|c|c|c|c|c|c|c|c|}
\hline & \multirow[b]{2}{*}{$n$} & \multicolumn{2}{|c|}{$\begin{array}{l}\text { Serving size } \\
\text { (g/serving) }\end{array}$} & \multicolumn{2}{|c|}{ SFA (g/serving) } & \multicolumn{2}{|c|}{$\begin{array}{c}\text { MUFA } \\
\text { (g/serving) }\end{array}$} & \multicolumn{2}{|c|}{$\begin{array}{c}\text { PUFA } \\
\text { (g/serving) }\end{array}$} & \multicolumn{2}{|c|}{$n-6$ (g/serving) } & \multicolumn{2}{|c|}{$n-3$ (g/serving) } & \multicolumn{2}{|c|}{ TFA (g/serving) } \\
\hline & & Mean & Min-max & Mean & Min-max & Mean & Min-max & Mean & Min-max & Mean & Min-max & Mean & Min-max & Mean & Min-max \\
\hline \multicolumn{16}{|l|}{ Industrial food } \\
\hline Biscuits & 4 & 88 & $82-98$ & $2 \cdot 8$ & $2 \cdot 7-2 \cdot 8$ & $2 \cdot 8$ & $2 \cdot 4-3 \cdot 2$ & $2 \cdot 0$ & $1 \cdot 1-3 \cdot 0$ & $2 \cdot 0$ & $1 \cdot 1-3 \cdot 0$ & 0.0 & $0.0-0.0$ & $0 \cdot 2$ & $0.1-0.5$ \\
\hline Chocolate & 4 & 33 & $33-33$ & $8 \cdot 1$ & $2 \cdot 2-16 \cdot 1$ & $7 \cdot 4$ & $2 \cdot 2-12 \cdot 7$ & 0.9 & $0.6-1.7$ & 0.9 & $0.5-1.6$ & 0.0 & $0.0-0.1$ & 0.7 & $0.0-2.6$ \\
\hline Ice cream & 4 & 56 & 33-71 & $5 \cdot 0$ & $1 \cdot 5-7 \cdot 2$ & 1.6 & $0.2-2.5$ & 0.5 & $0 \cdot 0-1 \cdot 1$ & 0.5 & $0 \cdot 0-1 \cdot 1$ & 0.0 & $0.0-0.0$ & 0.4 & $0.0-0.7$ \\
\hline Pretzels & 4 & 35 & 35-35 & 0.5 & $0.2-0.6$ & 0.8 & $0.4-1 \cdot 1$ & 1.9 & $1 \cdot 0-2 \cdot 8$ & 1.9 & $0.9-2.7$ & 0.0 & $0.0-0.0$ & 0.1 & $0.0-0.0$ \\
\hline Wafers & 4 & 89 & $81-94$ & $10 \cdot 9$ & $8 \cdot 7-14 \cdot 4$ & $8 \cdot 2$ & $6 \cdot 3-11 \cdot 0$ & $2 \cdot 8$ & $1 \cdot 9-5 \cdot 2$ & $2 \cdot 7$ & $1 \cdot 8-5 \cdot 1$ & 0.0 & $0.0-0.1$ & 0.5 & $0.1-1.9$ \\
\hline \multicolumn{16}{|l|}{ Home-made food } \\
\hline Cheburec & 2 & 117 & $98-137$ & 4.9 & $1 \cdot 6-8 \cdot 1$ & $4 \cdot 7$ & $3 \cdot 2-6 \cdot 1$ & $4 \cdot 1$ & $3 \cdot 4-4.9$ & $4 \cdot 0$ & $3 \cdot 2-4 \cdot 8$ & $0 \cdot 1$ & $0.1-0.1$ & 0.6 & $0 \cdot 0-1 \cdot 2$ \\
\hline Pateuri & 5 & 129 & 58-293 & $3 \cdot 2$ & $0.9-7.4$ & $5 \cdot 7$ & $1 \cdot 2-15 \cdot 5$ & $9 \cdot 1$ & $1.4-25.6$ & $9 \cdot 0$ & $1 \cdot 4-25 \cdot 3$ & 0.1 & $0.0-0.2$ & 0.2 & $0.1-0.4$ \\
\hline Sausage roll & 4 & 125 & $100-149$ & $3 \cdot 7$ & $3 \cdot 3-4 \cdot 1$ & $4 \cdot 8$ & $4 \cdot 4-5 \cdot 1$ & $3 \cdot 0$ & $1.9-3.5$ & $2 \cdot 8$ & $1 \cdot 7-3 \cdot 3$ & $0 \cdot 2$ & $0.1-0.2$ & $0 \cdot 1$ & $0.1-0.2$ \\
\hline Savoury plăcintă & 5 & 118 & $90-157$ & $6 \cdot 0$ & $2.9-9.2$ & $5 \cdot 2$ & $2 \cdot 2-11 \cdot 2$ & $5 \cdot 4$ & $2 \cdot 9-12 \cdot 7$ & $5 \cdot 3$ & $2 \cdot 9-12 \cdot 7$ & 0.1 & $0.0-0.1$ & 1.3 & $0.2-2.3$ \\
\hline Sweet doughnut & 4 & 49 & $34-61$ & 1.4 & $1 \cdot 1-2 \cdot 1$ & 3.0 & $2 \cdot 1-4 \cdot 3$ & $5 \cdot 1$ & $3 \cdot 6-7 \cdot 4$ & $5 \cdot 0$ & $3 \cdot 6-7 \cdot 4$ & 0.0 & $0.0-0.0$ & $0 \cdot 1$ & $0.1-0.2$ \\
\hline
\end{tabular}

Min, minimum; Max, maximum; TFA, trans-fatty acids.

v. $21 \cdot 4 \%$ in mobile vending sites, $P<0 \cdot 001)$. The most commonly available beverages were soft drinks $(80 \cdot 7 \%)$, water (77.0 \%), fruit juice-based drinks (57.6\%) and alcoholic beverages $(42 \cdot 0 \%)$ (Table 1$)$

\section{Nutritional composition}

Industrial foods were more energy-dense than home-made foods (median kJ/100 g: 1799.1 v. 1271.9, $P=0.002$ ), but the latter presented higher energy content per serving (median $\mathrm{kJ} /$ serving: $1312 \cdot 5 v \cdot 670 \cdot 3, P=0 \cdot 022$ ). The mean energy content per serving was highest in industrial and home-made sweet snacks: wafers (1909.6 kJ/serving) and sweet chiflă (1809.2 kJ/serving).

Kvass, a traditional low-alcohol fermented beverage, presented the lowest content in every macronutrient. The foods with the highest average protein content were home-made savoury pastries: sausage roll $(11.9 \mathrm{~g} /$ serving) and savoury plăcintă (10.1 g/serving). Industrial wafers (22.4 g/serving) and home-made pateuri (18.3 g/serving) showed the highest mean fat content and industrial chocolate and chocolate candy $(63.2 \mathrm{~g} /$ serving) and home-made sweet chiflă (61.4 g/serving) the highest mean carbohydrates' content (Table 2).

Regarding the lipid profile, the highest mean content in SFA and MUFA was found in industrial wafers (10.9 and $8.2 \mathrm{~g} / \mathrm{serv}$ ing, respectively) and industrial chocolate and chocolate candy ( 8.1 and $7.4 \mathrm{~g} /$ serving, respectively). The highest content in PUFA, particularly $n-6$, was found in home-made savoury pastries such as pateuri (9.1 and $9.0 \mathrm{~g} /$ serving, respectively) and plăcintă ( 5.4 and $5.3 \mathrm{~g} /$ serving, respectively). $n$ - 3 Fatty acids were present in reduced amounts in most foods; the maximum value was found 
Table 4. Nutritional composition (sodium, potassium and sodium:potassium ratio) of the street food samples evaluated by laboratorial analysis, per serving (Mean values and ranges)

\begin{tabular}{|c|c|c|c|c|c|c|c|c|c|}
\hline & \multirow[b]{2}{*}{$n$} & \multicolumn{2}{|c|}{$\begin{array}{l}\text { Serving size } \\
\text { (g/serving) }\end{array}$} & \multicolumn{2}{|c|}{$\mathrm{Na}$ (mg/serving) } & \multicolumn{2}{|c|}{$\mathrm{K}$ (mg/serving) } & \multicolumn{2}{|c|}{$\mathrm{Na}: \mathrm{K}$ ratio } \\
\hline & & Mean & Min-max & Mean & Min-max & Mean & Min-max & Mean & Min-max \\
\hline \multicolumn{10}{|l|}{ Industrial food } \\
\hline Biscuits & 4 & 88 & $82-98$ & 57 & $51-63$ & 55 & $31-68$ & $2 \cdot 0$ & $1 \cdot 3-3 \cdot 4$ \\
\hline Chocolate & 4 & 33 & $33-33$ & 2 & $0-8$ & 216 & $135-298$ & 0.0 & $0.0-0.1$ \\
\hline Ice cream & 4 & 56 & 33-71 & 30 & $15-46$ & 80 & 67-108 & 0.6 & $0.4-0.9$ \\
\hline Kvass & 4 & 200 & $200-200$ & 22 & $19-28$ & 14 & $13-15$ & $2 \cdot 8$ & $2 \cdot 5-3 \cdot 1$ \\
\hline Pretzels & 4 & 35 & $35-35$ & 285 & $135-640$ & 57 & $45-71$ & 8.7 & $4 \cdot 3-19 \cdot 9$ \\
\hline Wafers & 4 & 89 & $81-94$ & 127 & $73-188$ & 109 & $46-162$ & $2 \cdot 1$ & $1.5-2.7$ \\
\hline \multicolumn{10}{|l|}{ Home-made food } \\
\hline Cheburec & 2 & 117 & $98-137$ & 474 & $383-566$ & 152 & $127-178$ & $5 \cdot 3$ & $5 \cdot 1-5 \cdot 4$ \\
\hline Pateuri & 5 & 129 & $58-293$ & 447 & $201-1119$ & 175 & $32-583$ & $8 \cdot 3$ & $3 \cdot 2-25 \cdot 2$ \\
\hline Sausage roll & 4 & 125 & $100-149$ & 630 & 486-803 & 158 & $106-190$ & $7 \cdot 0$ & $4 \cdot 6-9 \cdot 6$ \\
\hline Savoury plăcintă & 5 & 118 & $90-157$ & 528 & $338-1029$ & 154 & $98-198$ & $5 \cdot 9$ & $3.5-10.5$ \\
\hline Sweet doughnut & 4 & 49 & $34-61$ & 100 & $52-146$ & 29 & 17-38 & $5 \cdot 6$ & $4 \cdot 2-6 \cdot 7$ \\
\hline Sweet plăcintă & 4 & 101 & $82-143$ & 186 & $107-357$ & 63 & $40-115$ & $6 \cdot 4$ & $2 \cdot 4-15 \cdot 0$ \\
\hline
\end{tabular}

Min, minimum; Max, maximum.

in home-made sausage roll $(0 \cdot 2 \mathrm{~g} /$ serving). Home-made sweet chiflă (1.4 g/serving) and savoury plăcintă (1.3 g/serving) presented the highest mean TFA content (Table 3).

Mean $\mathrm{Na}$ content ranged between $2 \mathrm{mg} /$ serving in industrial chocolate and chocolate candy and $774 \mathrm{mg} /$ serving in homemade sweet chiflă, whereas mean $\mathrm{K}$ content ranged between $12 \mathrm{mg} /$ serving in industrial kvass and $216 \mathrm{mg} / \mathrm{serving}$ in industrial chocolate. The average Na:K ratio was higher than 5 in most foods, reaching 8.7 in pretzels (Table 4).

\section{Discussion}

Street food vending sites selling food and beverages were highly frequent in Chişinău. Mostly industrial, but also home-made items were available, including a range of energy-dense confectionery, sweet and savoury snacks and pastries, high in SFA, TFA and Na.

This urban street food environment has particular characteristics. A higher proportion of stationary vending sites, mostly formal such as stands and kiosks, was found in Chişinău, in contrast with other urban settings in lower-middle-income country $^{(11,25,26)}$. Also, the street foods available were more frequently westernised food options (e.g. industrial snacks, confectionery and soft drinks), resembling characteristics of the nutrition transition occurring in Eastern Europe $e^{(1-3)}$. These foods, sugar-rich and energy-dense, may contribute to weight gain $^{(27)}$, mainly when presented in considerable serving sizes. Furthermore, alcoholic drinks were widely available, an additional source of public health concern, given their high consumption in the country and a strong association with the burden of $\mathrm{NCD}^{(28)}$

Home-made and industrial foods were found to have medium $(12.6 \mathrm{~kJ} / \mathrm{g})$ and high $(18.0 \mathrm{~kJ} / \mathrm{g})$ mean energy density, respectively ${ }^{(29)}$, which corroborates previous findings that street foods are energy-dense sources of nutrients for populations worldwide $^{(10)}$. Industrial wafers and biscuits presented the highest energy density (approximately $20.9 \mathrm{~kJ} / \mathrm{g}$ ), possibly reflecting a high sugar and fat content ${ }^{(30)}$, as previously observed in samples of street food in Dushanbe, Tajikistan ${ }^{(26)}$. Although the free sugar content was not discriminated in this study, they may have a high sugar content, which is line with existing literature on street food composition ${ }^{(10,25,26,31)}$.

Industrial wafers and home-made savoury pastries (e.g. pateuri and placintă) presented the highest fat content, approximately half of their total energy. Both industrial and home-made foods were found to be essential sources of SFA and TFA. Almost $25 \%$ of the energy of industrial wafers and $16 \%$ of the energy of some home-made sweet pastries came from SFA. For some home-made pastries, the contribution of TFA for the total energy reached approximately $3 \%$. One serving encompassed over half the daily WHO recommendation for TFA $(<1 \%$ total energy value/d), considering an average adult daily intake of $8368 \mathrm{~kJ}^{(32)}$ and exceeded the limit of $2 \mathrm{~g}$ TFA $/ 100 \mathrm{~g}$ fat, defined by the Eurasian Economic Union ${ }^{(33)}$ and the European Union ${ }^{(34)}$, with some food samples reaching $123 \%$ of the limit. The considerable variation in the SFA and TFA content of such home-made pastries may be due to the use of different cooking methods or to the type and quantity of the ingredients used ${ }^{(10,12)}$, particularly the fat sources ${ }^{(35)}$. The use of butter, even if in mixture with other fats, cannot be excluded, as it is a natural source of TFA, with a different relevance from industrially produced by hydrogenation.

The primary sources of protein were home-made savoury pastries, mostly meat-based, in line with the reported trend of high consumption of red and processed meat in Eastern Europe $^{(3,10,25)}$. These were also the primary Na sources, with one serving supplying, on average, $5 \cdot 1$ to $38.7 \%$ of the maximum daily recommended intake (100-774 mg $)^{(36)}$. These findings concur with national estimates that one serving of savoury pastries contained, on average, $512 \mathrm{mg}$ of $\mathrm{Na}$. This study also revealed that some sweet pastries contained a similar content, meaning that this nutrient may be hidden in foods where the consumer would not expect, as found in central Asian countries ${ }^{(37)}$. Most foods do not comply with the WHO recommendation of $\mathrm{Na}: \mathrm{K}$ ratio below $1^{(36)}$. In addition, fruit and vegetables, rich in $\mathrm{K}$, were infrequently observed in this street food environment. These findings 
reinforce concerns about the low consumption of these foods, and unbalanced $\mathrm{Na} / \mathrm{K}$ intake among the Moldovan population, markedly in urban settings ${ }^{(38,39)}$. Increasing the accessibility to these food options in urban Moldova could counterbalance the broader availability of unhealthier foods options, leading to better food choices among consumers ${ }^{(40)}$.

Street food products are available for consumption throughout the year, which is an opportunity for policy intervention. The improvement of the nutritional profile of the available street foods might be integrated in the National Strategy for Prevention and Control of NCD, which aims the shift towards healthy diets ${ }^{(38)}$, following recent international guidelines on sustainable food systems ${ }^{(41)}$. First, legislative approaches in cooperation with the food industry might be useful for effective salt reduction and TFA elimination, possibly through setting maximum limits in foods, food labelling or product reformulation. Additionally, given the central economic role of agriculture ${ }^{(42)}$, investing in local and sustainable food production would promote the availability of fresh and affordable fruits and vegetables in local markets. As evidenced in contexts where street food is part of the tradition ${ }^{(43)}$, addressing nutrition education actions for the general population and vendors would ultimately increase public knowledge and skills to create healthier recipes while maintaining the cultural identity. The future study of vendors' and consumers' nutritional literacy may contribute to design nutritional education strategies specific to their needs ${ }^{(44)}$.

\section{Strengths and limitations}

One of the strengths of this study is the fact that it was conducted in a region where the street food environment has been understudied $^{(14)}$, adding insight into the characteristics of more urbanised settings. The stepwise approach for data collection and analysis aimed to ensure an unbiased and comprehensive characterisation of the street food environment. Although the results may not be generalised to other communities due to local cultural specificities, the methodology has a vast potential to be adapted to different settings ${ }^{(17)}$, allowing comparison of results. The low proportion of fruit found in Chişinău is in line with findings in urban Tajikistan ${ }^{(26)}$; it should be noted that vending sites selling exclusively unprepared fresh fruit were not considered eligible in the FEEDcities study because these are usually more oriented to sell for household consumption and not for immediate consumption, as the definition of 'ready-to-eat' implies. The study was conducted in the summer, and the observed number and variability of types of vending sites might be higher than in other seasons, given that a substantial proportion of the informal vendors reported not working under adverse weather conditions. Additionally, as described in less urbanised settings, street foods may vary according to the agricultural seasonality $^{(11)}$. Nevertheless, we expect that in this urban area seasonality might affect mostly the availability of some ingredients used in the preparation of home-made street foods (e.g. fillings of sweet and savoury pastries), but not the availability of major food groups, neither their nutritional composition in terms of sugar, salt and fat. The routine implementation of this methodology would be an interesting tool to monitor several characteristics of the street food environment ${ }^{(45)}$ while minimising the issue of seasonal variability. The nutritional composition of the analysed street foods was estimated by chemical analysis, using reliable methodologies, which overcomes limitations of previous studies ${ }^{(3,10,14)}$.

\section{Conclusion}

In Chişinău, the street foods available include westernised options, coexisting with traditional home-made snacks and pastries, some of which very energy-dense and served in considerable serving sizes. It is imperative to improve the nutritional profile of street food while protecting its cultural and community role. Increasing fruit and vegetable availability, reducing salt content and encouraging the use of healthier fats is crucial to prevent diet-related NCD.

\section{Acknowledgements}

The authors would like to thank the support and collaboration of the Ministry of Health, Labour and Social Protection of the Republic of Moldova, WHO Country Office in Moldova, National Centre of Public Health and State University of Medicine and Pharmacy 'Nicolae Testemitanu'. The authors also extend their gratitude to Jo Jewell, for his crucial role in the implementation of the study and to Danielle Agnello and the team of interviewers, for their commitment and dedication during fieldwork.

The FEEDcities project was funded by the World Health Organization Europe (WHO registration 2015/591370 and 2017/698514). This study was funded by national funds through FCT - Fundação para a Ciência e a Tecnologia, I.P., under the projects UIDB/04750/2020 and UID/QUI/50006/2020. Individual $\mathrm{PhD}$ grants attributed to G. A. (SFRH/BD/118630/ 2016) and S. S. (SFRH/BD/130650/2017) were funded by FCT and the 'Programa Operacional Capital Humano' (POCH/FSE). The funders had no role in the design, analysis or writing of this article.

M. G., P. M., J. B., N. L. and P. P. designed the study. I. L. d. M. and M. G. supervised the study implementation and data collection. O. P. and S. C. were responsible for the chemical analysis of the food samples collected. G. A., N. L. and P. P. performed the analysis and interpretation of the results. G. A. drafted the manuscript. All authors critically revised the manuscript and gave their final approval of the manuscript submitted for publication.

The authors declare that they have no conflicts of interest. J. B. is a staff member of the WHO Regional Office for Europe. The author is responsible for the views expressed in this publication, and they do not necessarily represent the decisions or stated policy of the WHO.

\section{Supplementary material}

For supplementary material/s referred to in this article, please visit https://doi.org/10.1017/S0007114520002020

\section{References}

1. Ulijaszek SJ \& Koziel S (2007) Nutrition transition and dietary energy availability in Eastern Europe after the collapse of communism. Econ Hum Biol 5, 359-369. 
2. Food and Agriculture Organization (2017) Europe and Central Asia: Regional Overview of Food Insecurity 2016. The Food Insecurity Transition. Budapest, Hungary: Food and Agriculture Organization of the United Nations.

3. Afshin A, Sur PJ, Fay KA, et al. (2019) Health effects of dietary risks in 195 countries, 1990-2017: a systematic analysis for the Global Burden of Disease Study 2017. Lancet 393, 1958-1972.

4. Popkin BM \& Gordon-Larsen P (2004) The nutrition transition: worldwide obesity dynamics and their determinants. Int J Obes Relat Metab Disord 28, Suppl. 3, S2-S9.

5. World Health Organization (2018) Noncommunicable Diseases (NCD) Country Profile: Moldova. Copenhagen, Denmark: WHO Regional Office for Europe.

6. Popkin BM (1999) Urbanization, lifestyle changes and the nutrition transition. World Dev 27, 1905-1916.

7. Food and Agriculture Organization (1989) Street foods. Report of an FAO Expert Consultation, Jogjakarta, Indonesia, 5-9 December 1988. FAO Food Nutr Pap 46, 1-96.

8. World Health Organization (1996) Essential Safety Requirements for Street-Vended Foods, rev. ed. Geneva: WHO.

9. Winarno F \& Allain A (1991) Street foods in developing countries: lessons from Asia. Food Nutr Agric 1, 11-18.

10. Steyn NP, McHiza Z, Hill J, et al. (2014) Nutritional contribution of street foods to the diet of people in developing countries: a systematic review. Public Health Nutr 17, 1363-1374.

11. Fellows P \& Hilmi M (2012) Selling Street and Snack Foods. Rome, Italy: Rural Infrastructure and Agro-Industries Division of the Food and Agriculture Organization of the United Nations.

12. Draper A (1996) Street Foods in Developing Countries: The Potential for Micronutrient Fortification. London, UK: London School of Hygiene and Tropical Medicine.

13. Simopoulos A \& Bhat R (2000) Street Foods. World Review of Nutrition and Dietetics, vol. 86. Basel: Karger.

14. Abrahale K, Sousa S, Albuquerque G, et al. (2019) Street food research worldwide: a scoping review. J Hum Nutr Diet 32, $152-174$.

15. Namugumya BS \& Muyanja C (2012) Contribution of street foods to the dietary needs of street food vendors in Kampala, Jinja and Masaka districts, Uganda. Public Health Nutr 15, 1503-1511.

16. Rippin HL, Hutchinson J, Evans CEL, et al. (2018) National nutrition surveys in Europe: a review on the current status in the 53 countries of the WHO European region. Food Nutr Res 62, 10.29219/fnr.v62.1362

17. World Health Organization (2019) FEEDcities - A comprehensive characterisation of the street food environment in cities Project protocol. http://www.euro.who.int/_data/assets/pdf file/0009/396783/WHO-FEED-protocol-report_v5.pdf?ua=1 (accessed December 2019).

18. World Bank (2020) The World Bank: Moldova. http://data worldbank.org/country/moldova (accessed April 2020).

19. National Bureau of Statistics of the Republic of Moldova (2019) Statistical Databank. Number of Population. Chisinau, Moldova: National Bureau of Statistics of the Republic of Moldova.

20. Monteiro CA, Cannon G, Moubarac JC, et al. (2018) The UN Decade of Nutrition, the NOVA food classification and the trouble with ultra-processing. Public Health Nutr 21, 5-17.

21. Horwitz W (2000) Official Methods of Analysis, vol. 1. Washington, DC: Association of The Official Analytical Chemists.

22. Costa N, Cruz R, Graca P, et al. (2016) Trans fatty acids in the Portuguese food market. Food Control 64, 128-134.
23. Vieira E, Elisa Soares M, Ferreira I, et al. (2012) Validation of a fast sample preparation procedure for quantification of sodium in bread by flame photometry. Food Anal Methods $\mathbf{5}$, 430-434.

24. World Health Organisation (2020) e-Library of Evidence for Nutrition Actions (eLENA). Potassium intake for adults and children: Guidance summary. https://www.who.int/elena/titles/guidance_ summaries/potassium_intake/en/ (accessed May 2020).

25. Sousa S, Gelormini M, Damasceno A, et al. (2018) Street food in Maputo, Mozambique: availability and nutritional value of homemade foods. Nutr Health 25, 37-46.

26. Albuquerque G, Morais I, Gelormini M, et al. (2019) Street food in Dushanbe, Tajikistan: availability and nutritional value. $\mathrm{BrJ}$ Nutr 122, 1052-1061.

27. World Health Organization (2015) Guideline: Sugars Intake for Adults and Children. Geneva: WHO.

28. World Health Organization (2018) Global Status Report on Alcohol and Health 2018. Geneva: WHO.

29. Rolls BJ (2017) Dietary energy density: applying behavioural science to weight management. Nutr Bull 42, 246-253.

30. Moodie R, Stuckler D, Monteiro C, et al. (2013) Profits and pandemics: prevention of harmful effects of tobacco, alcohol, and ultra-processed food and drink industries. Lancet $\mathbf{3 8 1}$, 670-679.

31. Koodagi K, Kendra KV, Farm V, et al. (2013) Macronutrient status of street foods. J Nutr Food Sci 3, 198.

32. Uauy R, Aro A, Clarke R, et al. (2009) WHO scientific update on trans fatty acids: summary and conclusions. Eur J Clin Nutr $\mathbf{6 3}$, S68-S75.

33. Eurasian Economic Commission (2011) Technical regulation on butter and fat products. In TP TC 024/2011. Moscow, Russia: Eurasian Economic Commission.

34. European Union (2019) Commission Regulation amending Annex III to Regulation (EC) No 1925/2006 of the European Parliament and of the Council as regards trans fat, other than trans fat naturally occurring in fat of animal origin. In Commission Regulation (EU) 2019/649. Brussels, Belgium: European Union.

35. Gupta V, Downs SM, Ghosh-Jerath S, et al. (2016) Unhealthy fat in street and snack foods in low-socioeconomic settings in India: a case study of the food environments of rural villages and an urban slum. J Nutr Educ Behav 48, 269-279.e261.

36. World Health Organization (2012) Guideline: Sodium Intake for Adults and Children. Geneva: WHO.

37. Lanca de Morais I, Lunet N, Albuquerque G, et al. (2018) The sodium and potassium content of the most commonly available street foods in Tajikistan and Kyrgyzstan in the context of the FEEDCities project. Nutrients $\mathbf{1 0}, 98$.

38. World Health Organization (2018) Dietary Salt Intake Survey in The Republic of Moldova, 2016. Copenhagen, Denmark: WHO - Regional Office for Europe.

39. Goryakin Y, Rocco L, Suhrcke M, et al. (2015) Fruit and vegetable consumption in the former Soviet Union: the role of individual- and community-level factors. Public Health Nutr 18, 2825-2835.

40. Tester JM, Yen IH \& Laraia B (2010) Mobile food vending and the after-school food environment. Am J Prev Med $\mathbf{3 8}$, 70-73.

41. Willett W, Rockström J, Loken B, et al. (2019) Food in the Anthropocene: the EAT Lancet Commission on healthy diets from sustainable food systems. Lancet 393, 447-492.

42. National Bureau of Statistics of the Republic of Moldova (2020) Contribution of economic activities in the GDP formation, 
current prices, CAEM Rev. 2 by Economic activities and years. https://statbank.statistica.md/pxweb/pxweb/en/40 \%20Statistica $\% 20$ economica/40 \%20Statistica\%20economica_13\%20CNT_ SCN2008_CNT010_Resurse/CNT010072.px/table/tableView Layout1/?rxid=9a62a0d7-86c4-45da-b7e4-fecc26003802\%22\% 20class=\%22link_mail (accessed April 2020).

43. Hawkes C, Jewell J \& Allen K (2013) A food policy package for healthy diets and the prevention of obesity and diet-related non-communicable diseases: the nourishing framework. Obes Rev 14, 159-168.

44. World Health Organization (2013) Health Literacy: The Solid Facts. Copenhagen, Denmark: WHO - Regional Office for Europe.

45. Gelormini M, Padrão P, Lunet N, et al. (2017) Monitoring and surveillance of street food vendors to prevent NCDs: the FEEDCities project. Public Health Panorama 3, 537-820. 